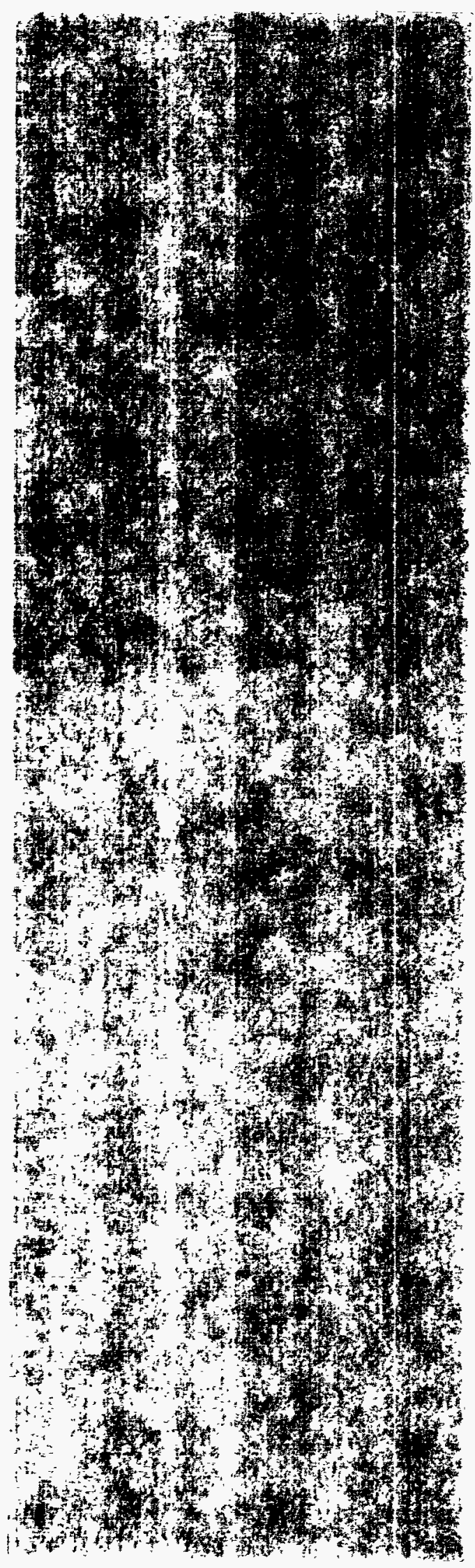

\section{Calibration and Performance Testing of the} IAEA Aquila Active Well Coincidence Counter

\section{(Unit 1)}

\section{UNITED STATES PROGRAM \\ FOR TECHNICAL ASSISTANCE TO IAEA SAFEGUARDS

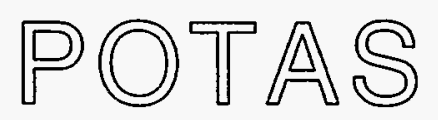 \\ DEPARTMENT OF STATE \\ DEPARTMENT OF ENERGY \\ ARMS CONTROL AND DISARMAMENT AGENCY NUCLEAR REGULATORY COMMISSION \\ Los Alamos}

Los Alamos National Laboratory is operated by the University of California for the United States Department of Energy under contract W-7405-ENG-36. 
Edited by Paul W. Henriksen, Group CIC-1

Prepared by Celina M. Ortiz, Group NIS-5

This work was supported by the U.S. Department of Energy, Office of Nonproliferation and National Security, International Safeguards Division, and Program for Technical Assistance to IAEA Safeguards.

An Affirmative Action/Equal Opportunity Employer

This report was prepared as an account of work sponsored by an agency of the United States Government. Neither The Regents of the University of California, the United States Government nor any agency thereof, nor any of their employees, makes any warranty, expressor implied, or assumes any legal liability or responsibility for the accuracy, completeness, or usefulness of any information, apparatus, product, or process disclosed, or represents that its use would not infringe privately owned rights. Reference herein to any specific commercial product, process, or service by trade name, trademark, manufacturer, or otherwise, does not necessarily constitute or imply its endorsement, recommendation, or favoring by The Regents of the University of California, the United States Government, or any agency thereof. The views and opinions of authors expressed herein do not necessarily state or reflect those of The Regents of the University of California, the United States Government, or any agency thereof. The Los Alamos National Laboratory strongly supports academic freedom and a researcher's right to publish; therefore, the Laboratory as an institution does not endorse the viewpoint of a publication or guarantee its technical correctness. 
Calibration and Performance Testing of the IAEA Aquila Active Well Coincidence Counter (Unit 1)

H. O. Menlove

R. Siebelist

T. R. Wenz 


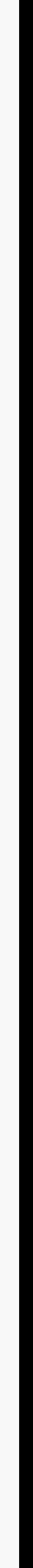




\section{CONTENTS}

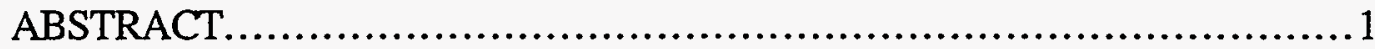

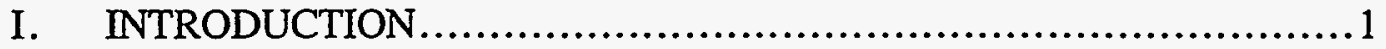

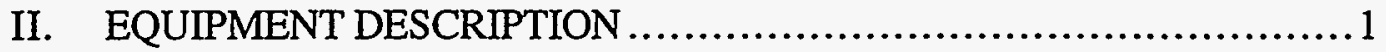

III. QUALITY CHECKS AND PERFORMANCE TESTS....................1

A. High-Voltage-Plateau Curve .........................................2

B. Amptek Amplifier Check ...........................................2

C. Efficiency........................................................... 2

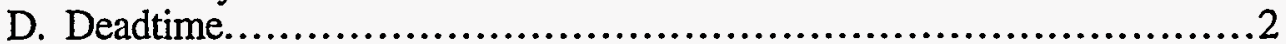

E. Noise Test ............................................................... 4

F. AmLi Sources..................................................... 4

IV. CROSS-CALIBRATION ...............................................4

V. FUEL ASSEMBLY CALIBRATION................................6

VI. SOFTWARE COMPATIBILITY ......................................6

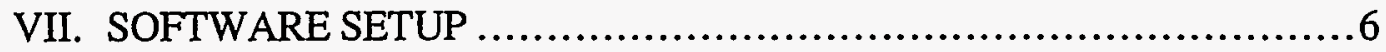

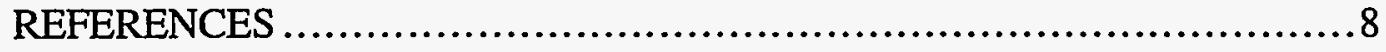

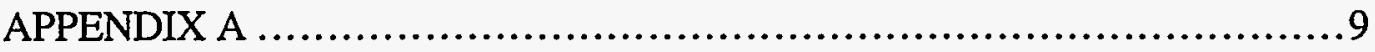

APPENDIX B ................................................................ 11 



\title{
CALIBRATION AND PERFORMANCE TESTING OF THE IAEA AQUILA ACTIVE WELL COINCIDENCE COUNTER (UNIT 1)
}

\author{
by
}

H. O. Menlove, R. Siebelist, and T. R. Wenz

\begin{abstract}
An Active Well Coincidence Counter (AWCC) and a portable shift register (PSR-B) produced by Aquila Technologies Group, Inc., have been tested and cross-calibrated with existing AWCCs used by the International Atomic Energy Agency (IAEA). This report summarizes the results of these tests and the crosscalibration of the detector. In addition, updated tables summarizing the cross-calibration of existing AWCCs and AmLi sources are also included. Using the Aquila PSR-B with existing IAEA software requires secondary software also supplied by Aquila to set up the PSR-B with the appropriate measurement parameters.
\end{abstract}

\section{INTRODUCTION}

This Active Well Coincidence Counter (AWCC) produced by Aquila Technologies Group, Inc., was tested at Los Alamos National Laboratory in August 1995. The testing was done to determine the operating characteristics, to find mechanical or electrical problems, and to crosscalibrate the instrument with existing AWCCs. ${ }^{1}$

We also calibrated the specially fabricated fuel rod insert supplied with this instrument ${ }^{2}$ for uranium fuel rod bundles.

\section{EQUIPMENT DESCRIPTION}

This AWCC has serial number 1001. Forty two ${ }^{3} \mathrm{He}$ detectors (RS-P4-0820-107) are connected in groups of seven tubes. Each group has one Amptek preamp/amplifier/discriminator board. All six of the Amptek units are ORed together to a common signal-output connector.

A LANL-supplied ISR-12 shift register coincidence counter was used during the initial testing while Aquila Technologies was modifying the PSR-B.

\section{QUALITY CHECKS AND PERFORMANCE TESTS}

A physical examination of the instrument revealed the following:

1. The ${ }^{3} \mathrm{He}$ tubes were loose and could be turned by hand. They were tightened.

2. One ${ }^{3} \mathrm{He}$ tube in bank \#3 has a small dent. Aquila was aware of it and has spoken to the vendor. There is no indication of any malfunction in this tube and it was left in the system. 
3. The ${ }^{3} \mathrm{He}$ tubes used in the detector contain a fill gas with a carbon dioxide additive formerly specified by LANL for the original AWCCs. An argon-methane fill gas mix is currently used, and Aquila will use ${ }^{3} \mathrm{He}$ tubes of this type in future detectors.

4. The humidity indicators in the original junction box lid were missing the desiccant tubes. Aquila delivered a replacement lid with the proper desiccant fixtures installed. The unit now has adequate desiccant.

5. The LED indicator lights were loose in their holes. They were subsequently fixed in place with silicone sealant.

6. The handle on the AWCC was made of a thin-walled tubing causing a bowing sensation whenever the detector was tipped on its side for the fuel assembly measurements. Newer versions of the detector handle are made with a thicker-walled tubing.

\section{A. High-Voltage-Plateau Curve}

We plotted the totals counting rate vs the high-voltage setting to determine the operating highvoltage to be used (see Fig. 1). A setting of $1760 \mathrm{~V}$ was chosen. This is somewhat higher than the $1680 \mathrm{~V}$ used for the High-Level Neutron Coincidence Counter (HLNC-II) because of the carbon dioxide gas mix in the ${ }^{3} \mathrm{He}$ tubes.

\section{B. Amptek Amplifier Check}

The individual detector banks were tested by comparing the totals rate from a neutron source centered in the AWCC. The goal was to determine if one or more ${ }^{3} \mathrm{He}$ tubes are malfunctioning in any of the banks. $\mathrm{A}^{252} \mathrm{Cf}$ source (CR-6) was used for the comparison, and the results are listed in Table I.

The ${ }^{3} \mathrm{He}$ detector tubes are wired in an alternating three inner ring plus four outer ring pattern for each preamplifier. This should result in the measured count rate alternating higher to slightly lower as each tube bank is measured. A 1-in-7 difference is not observed in the data listed in Table I, indicating that all the ${ }^{3} \mathrm{He}$ tubes are functioning. The gain and discriminator threshold settings were checked and found to be correct for all six amplifier channels.

\section{Efficiency}

Californium-252 source CR-6 was used to measure the totals efficiency in the Mode 1 configuration (see Fig. 2, Ref. 1). This was determined to be $23 \%$, which is consistent with other AWCCs in use.

\section{Deadtime}

The totals and reals deadtime correction parameters were measured by using two ${ }^{2.52} \mathrm{Cf}$ sources of different strengths. The reals ratio of sources CR-10 to CR-5 is 84.4. The resulting deadtime coefficients are

$$
\begin{aligned}
& a=0.808 \mu \mathrm{s} \text { and } \\
& b=0.261 \mu \mathrm{s}^{2} .
\end{aligned}
$$




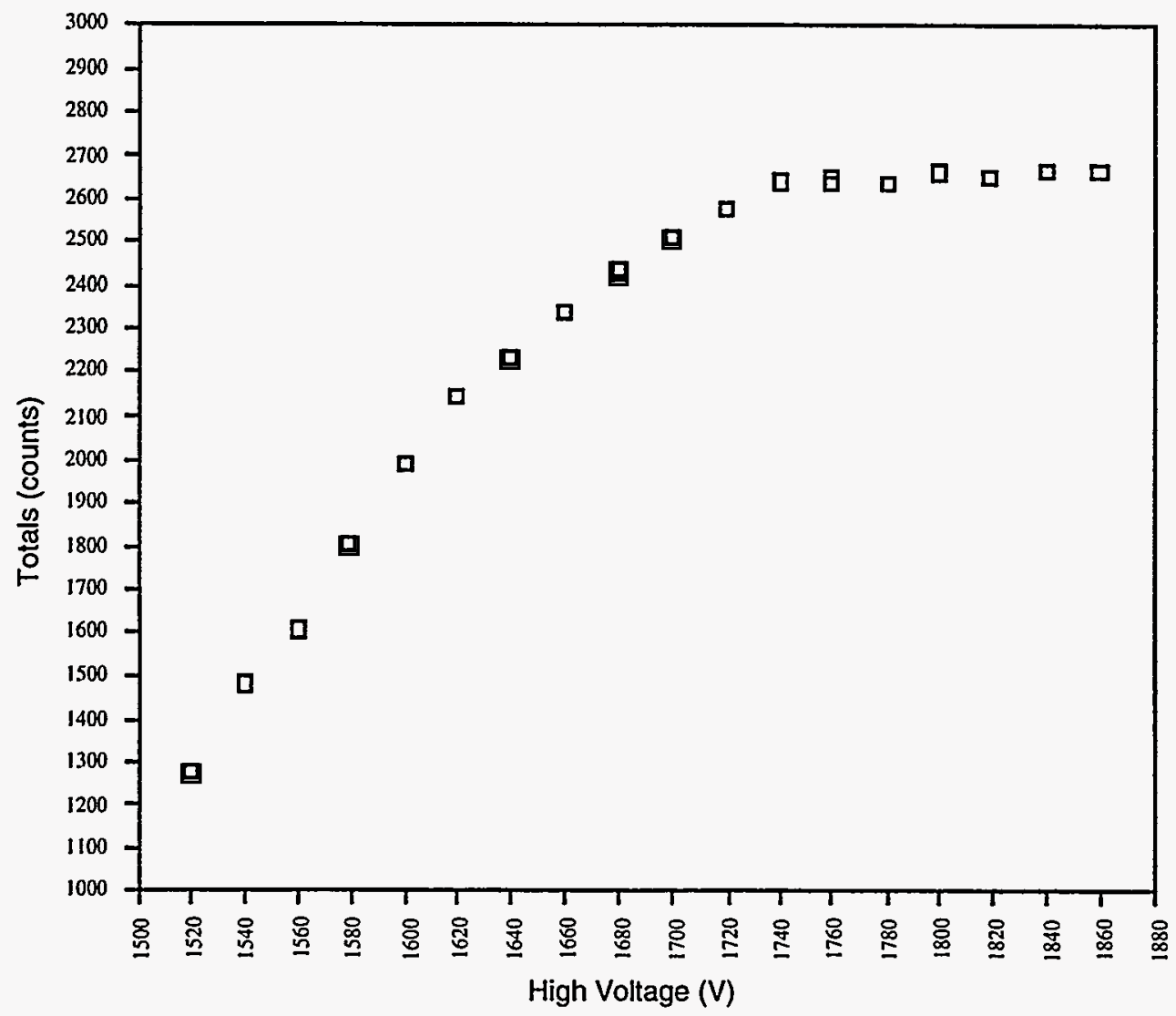

Fig. I. Detector bias plateau curve for the AWCC. The recommended operating voltage is $1760 \mathrm{~V}$.

\begin{tabular}{|c|c|c|}
\hline TABLE I. & \multicolumn{2}{c|}{$\begin{array}{c}\text { Results of Individual } \\
\text { Detector Bank Measurements }\end{array}$} \\
\hline \hline Detector Bank & $\begin{array}{c}\text { Totals Rate } \\
\text { (counts/s) }\end{array}$ & $\begin{array}{c}\text { Sigma } \\
\text { (counts/s) }\end{array}$ \\
\hline 1 & 410.02 & 2.12 \\
2 & 422.57 & 2.57 \\
3 & 408.23 & 2.02 \\
4 & 409.67 & 2.02 \\
5 & 400.70 & 2.00 \\
6 & 431.32 & 2.08 \\
\hline
\end{tabular}




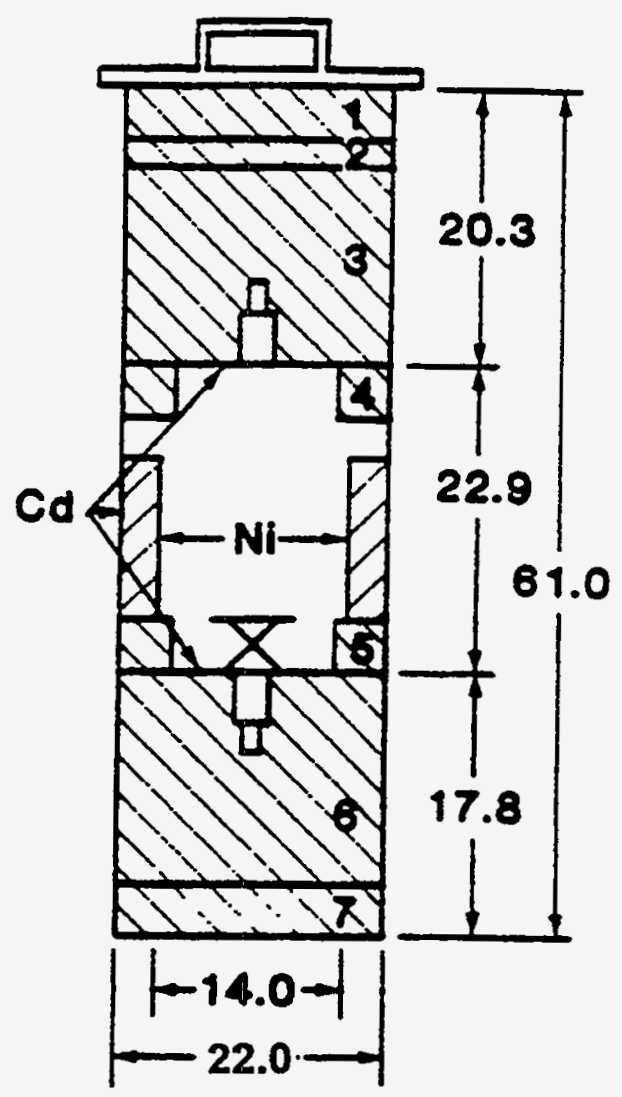

Fig. 2. Cross section of AWCC end plug configuration and sample position, Fast Mode 1, used for the cross-calibration exercise.

\section{E. Noise Test}

The AWCC was set up in the fast mode configuration to measure room background without the end plugs and AmLi sources for 27 hours in 4000 -s counting intervals. The results of these measurements are shown in Table II where the totals and reals rates are listed with their corresponding statistical errors for each of the measurements. Two runs with cosmic-ray spallation events were eliminated from the data set by the outlier test resulting in the lower coincident background rate listed at the bottom of Table II. The unit is free of any electronic noise problems.

\section{F. AmLi Sources}

The AmLi neutron sources supplied with this AWCC are labeled NO61 and NO73. These sources were counted relative to AmLi source MRC-95. The deadtime-corrected totals rates relative to MRC-95 are 1.197 for NO61 and 1.128 for NO73. These values will be added to Table XX of Ref. 1 (see Appendix A).

\section{CROSS-CALIBRATION}

We cross-calibrated for high-enriched uranium (HEU) metal under the following conditions:

1. AWCC in Mode I (Ref. 1) geometry with the nickel reflector ring in place (see Fig. 2).

2. AmLi source NO73 in the top end plug and AmLi source NO61 in the bottom end plug. Both AmLi source containers have their screw caps directed away from the sample cavity. 


\begin{tabular}{|c|c|c|c|c|}
\hline \multicolumn{5}{|c|}{ TABLE II. Results of Background Measurements } \\
\hline \hline Run & $\begin{array}{c}\text { Totals } \\
\text { (counts/s) }\end{array}$ & $\begin{array}{c}\text { sig-T } \\
\text { (counts/s) }\end{array}$ & $\begin{array}{c}\text { Reals } \\
\text { (counts/s) }\end{array}$ & $\begin{array}{c}\text { sig-R } \\
\text { (counts/s) }\end{array}$ \\
\hline 1 & 4.096 & 0.032 & 0.022 & 0.002 \\
2 & 4.123 & 0.032 & 0.016 & 0.002 \\
3 & 4.047 & 0.032 & 0.016 & 0.002 \\
4 & 4.024 & 0.032 & 0.019 & 0.002 \\
5 & 3.975 & 0.032 & 0.017 & 0.002 \\
6 & 3.966 & 0.031 & 0.014 & 0.002 \\
7 & 4.095 & 0.032 & 0.018 & 0.002 \\
8 & 4.053 & 0.032 & 0.015 & 0.002 \\
9 & 4.056 & 0.032 & 0.018 & 0.002 \\
10 & 4.043 & 0.032 & 0.019 & 0.002 \\
11 & 4.035 & 0.032 & 0.013 & 0.002 \\
12 & 4.048 & 0.032 & 0.021 & 0.002 \\
13 & 4.134 & 0.032 & 0.014 & 0.002 \\
14 & 4.072 & 0.032 & 0.017 & 0.002 \\
15 & 4.085 & 0.032 & 0.023 & 0.002 \\
16 & 4.062 & 0.032 & 0.016 & 0.002 \\
17 & 4.036 & 0.032 & 0.017 & 0.002 \\
18 & 4.002 & 0.032 & 0.019 & 0.002 \\
19 & 4.019 & 0.032 & 0.018 & 0.002 \\
20 & 4.069 & 0.032 & 0.021 & 0.002 \\
21 & 4.037 & 0.032 & 0.018 & 0.002 \\
22 & 4.013 & 0.032 & 0.016 & 0.002 \\
23 & 4.055 & 0.032 & 0.022 & 0.002 \\
24 & 4.043 & 0.032 & 0.013 & 0.002 \\
\hline Ave & 4.049 & 0.008 & 0.017 & 0.001 \\
\hline
\end{tabular}


3. AWCC in Fast Mode configuration, all cadmium in place.

4. The HEU disk $\mathrm{C} 20-8$ positioned 2 in. $(5 \mathrm{~cm})$ above the bottom on an aluminum stand.

Metal disk $\mathrm{C} 20-8$ has a ${ }^{235} \mathrm{U}$ mass of $246.28 \mathrm{~g}$. The measured reals response was $37.810 \pm$ 0.439 counts/s. The response for this metal disk relative to the reference AWCC will be added to Table V of Ref. 1 (see Appendix B).

\section{FUEL ASSEMBLY CALIBRATION}

The fuel rod insert, as supplied by Aquila, includes a source holder that separates the sources in the insert by about $127 \mathrm{~mm}$ (see Fig. 3a). The fuel assembly measurements made by Krick ${ }^{2}$ had the sources together at the center of the insert (see Fig. 3b). The calibration measurements were performed with the sources in both geometries. The results of these measurements are grouped by geometry in Table III.

The response is $9.6 \%$ higher with the sources together in the center than for the sources separated by $127 \mathrm{~mm}$. With the sources separated, an increase in end leakage of neutrons occurs accounting for the reduction in response.

\section{SOFTWARE COMPATIBILITY}

The IAEA uses the Active Neutron Counting System (ANCS) software with the AWCC. This software was originally designed to operate with an AWCC and a JSR-11 shift register. Parameters such as count time, gate width, high voltage, and predelay would be set by the operator using the external manual controls on the JSR-11. The ANCS software is then used to start the measurement, collect the data from the shift register at the end of the measurement, and perform the required data analysis to obtain grams of ${ }^{235} \mathrm{U}$. The software does not set any of the shift register parameters mentioned above.

With the Aquila PSR-B, there are no external manual controls for setting the high voltage, count time, gate width, predelay, or baud rate; software is required to set these parameters. Consequently, when the Aquila PSR-B is used with the ANCS software, these setup parameters must be preset using default values or an auxiliary software code supplied by Aquila. To this end, Aquila has supplied two programs for setting and resetting the parameters on the PSR-B. This software is executed before starting the ANCS software. The first program, INIT.EXE, sets the shift register parameters to those in Table V and displays the current settings and status of the PSR$B$. The second program, PARAM.EXE, provides an interface so the operator can change any of the shift register parameters listed in Table V except the baud rate.

\section{SOFTWARE SETUP}

Before starting the ANCS software for taking measurements, the measurement parameters on the PSR-B need to be set or verified with software or both. There are two programs to do this: INIT.EXE and PARAM.EXE. The software can either be loaded onto the hard drive of the controlling computer or used from the diskette. If desired, a call to these programs could be included in the batch file that starts the ANCS program.

Running the INIT program results in the PSR-B measurement parameters being set to those listed in Table V. No user input is required. On the computer screen, the current status of the PSR-B is displayed along with the current shift register parameters. Once the parameters are set, 


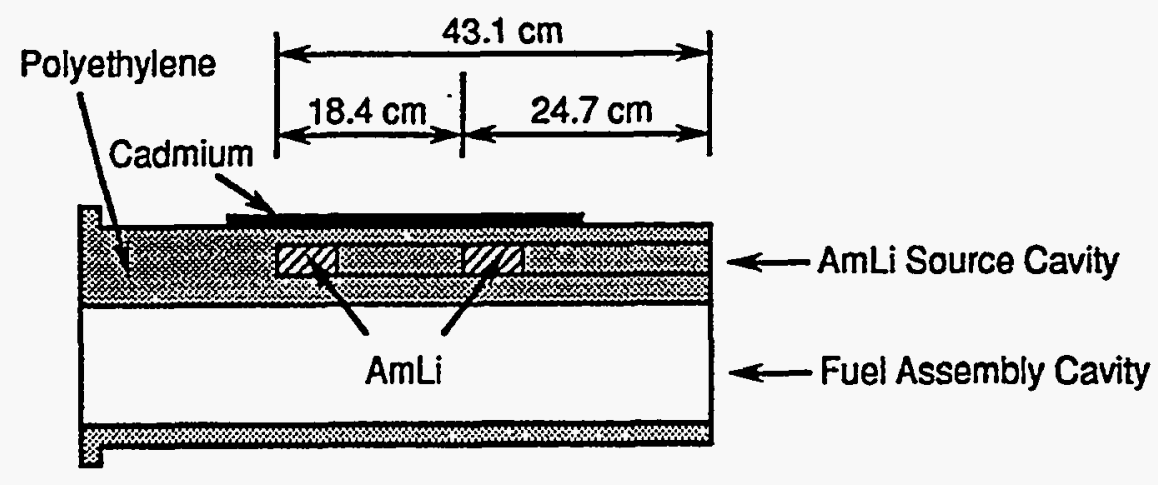

(a) Separated Source Position

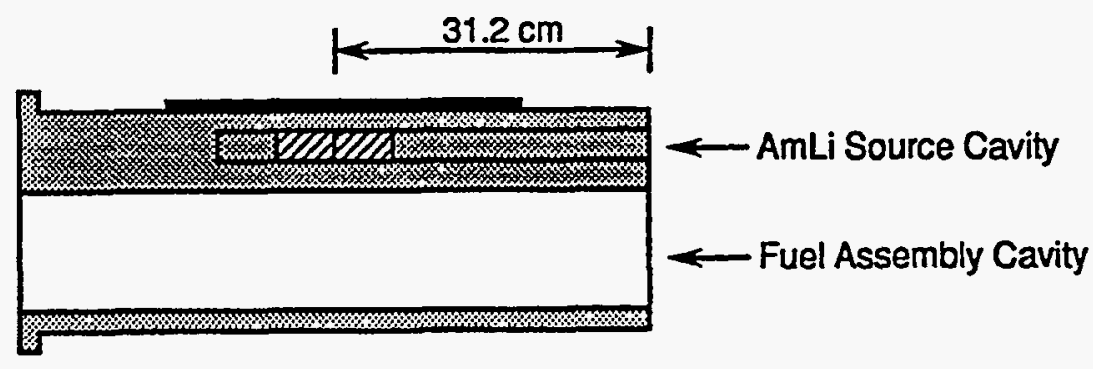

(b) Centered Source Position

Fig. 3. Cross section of fuel assembly insert for measuring fuel assemblies showing separated (a) and centered (b) source positions used to measure data in Table III.

TABLE III. Calibration Results for Uranium Fuel Rod Bundles

\begin{tabular}{|c|c|c|c|c|c|}
\hline \hline $\begin{array}{c}\text { Source } \\
\text { Position }\end{array}$ & $\mathrm{gU} / \mathrm{cm}$ & $\begin{array}{c}\text { No. of } \\
\text { Pins }\end{array}$ & $\begin{array}{c}\mathrm{g}^{235} \mathrm{U} \\
\text { per } \mathrm{cm}\end{array}$ & $\begin{array}{c}\text { Reals Rate } \\
\text { (counts/s) }\end{array}$ & $\begin{array}{c}\text { Sigma } \\
\text { (counts/s) }\end{array}$ \\
\hline separated & 0.0 & 0 & 0.00 & 0.01 & 0.002 \\
separated & 315.7 & 53 & 10.07 & 58.66 & 1.44 \\
& & & & & \\
centered & 315.7 & 53 & 10.07 & 63.89 & 0.69 \\
\hline
\end{tabular}




\begin{tabular}{|c|c|}
\hline \multicolumn{2}{|c|}{$\begin{array}{l}\text { TABLE V. } \\
\text { Shift Register } \\
\text { Parameters } \\
\text { Supplied to the } \\
\text { PSR-B from the } \\
\text { INIT Program. } \\
\end{array}$} \\
\hline Parameter & Value \\
\hline Baud Rate & 300 \\
\hline Count Time & $100 \mathrm{~s}$ \\
\hline Gate Width & $64 \mu s$ \\
\hline High Voltage & $1760 \mathrm{~V}$ \\
\hline Predelay & $4.5 \mu \mathrm{s}$ \\
\hline
\end{tabular}

they are stored in a Programmable Read Only Memory (PROM) chip so that the next time the PSR$B$ power is turned on, the same values will be used. The stored values are updated whenever INIT or PARAM are run. Once the parameters are loaded, the ANCS software can be started to begin the measurements.

To set the shift register parameters to values other than those listed in Table $V$ requires the PARAM program. When running PARAM, the current status and shift register parameters for the PSR-B are displayed on the screen and the user is asked whether to change any of the values. If the response is yes, the user is prompted for values of each of the parameters in Table V except the baud rate. If no is selected, no changes are made and the program exits.

Occasionally when starting a measurement with the ANCS software, the user will see an error message saying the instrument is not ready. Simply press F3 to start the measurement again and communication will be established with the PSR-B.

\section{REFERENCES}

1. H. O. Menlove and J. E. Stewart, "A New Method of Calibration and Normalization for Neutron Detector Families," Los Alamos National Laboratory report LA-11229-MS (ISPO287) (April 1988).

2. M. S. Krick, L. R. Cowder, et al., "Active Well Coincidence Counter Measurements of Enriched Uranium Fuel Assemblies in Scanning and Stationary Modes," Los Alamos National Laboratory report LA-12224-MS (ISPO-334) (December 1991). 


\section{APPENDIX A}

(Updated Version of Table XX from LA-11229-MS)

TABLE XX. AmLi Source Yield Comparison ${ }^{\mathrm{a}}$

Yield Relative to

\begin{tabular}{|c|c|c|c|}
\hline Source No. & MRC-95 & $\underline{\text { IAEA }}$ & Location \\
\hline MRC-67 & 0.554 & & Los Alamos \\
\hline MRC-68 & 2.872 & & Los Alamos \\
\hline MRC-75 & 0.1760 & & IAEA \\
\hline MRC-77 & 0.1633 & $(0.165)$ & IAEA \\
\hline MRC-79 & 1.107 & & \\
\hline MRC-80 & 1.062 & & \\
\hline MRC-81 & 1.037 & & \\
\hline MRC-82 & 0.956 & & \\
\hline MRC-91 & 0.995 & & IAEA \\
\hline MRC-92 & 0.996 & & IAEA \\
\hline MRC-93 & 1.042 & & IAEA \\
\hline MRC-94 & 1.013 & & Los Alamos \\
\hline MRC-95 & 1.000 & & Los Alamos/EURATOM \\
\hline MRC-96 & 1.009 & & Los Alamos \\
\hline MRC-99 & 1.899 & & Los Alamos \\
\hline MRC-100 & 1.845 & & Los Alamos \\
\hline MRC-104 & 1.144 & & IAEA \\
\hline MRC-105 & 1.106 & & IAEA \\
\hline MRC-110 & 1.048 & & IAEA \\
\hline MRC-111 & 1.132 & & IAEA \\
\hline MRC-112 & 1.150 & & IAEA \\
\hline MRC-113 & 1.211 & & Los Alamos/IAEA \\
\hline MRC-114 & 1.164 & & Los Alamos/IAEA \\
\hline MRC-115 & 1.287 & & Los Alamos \\
\hline MRC-116 & 1.305 & $(1.289)$ & Los Alamos \\
\hline MRC-117 & 1.220 & & Los Alamos \\
\hline MRC-118 & 1.220 & & Los Alamos \\
\hline MRC-121 & 1.628 & & EURATOM \\
\hline C-119 & 1.142 & & EURATOM \\
\hline$C-171$ & 1.217 & & \\
\hline $\mathrm{C}-172$ & 1.193 & $(1.180)$ & IAEA \\
\hline C- 173 & 1.176 & & \\
\hline C- 174 & 1.223 & & \\
\hline$C-176$ & 1.255 & & EURATOM \\
\hline$C-180$ & 1.270 & & EURATOM \\
\hline C- 181 & 1.211 & & EURATOM \\
\hline C- 182 & 1.193 & & EURATOM \\
\hline C-183 & 1.176 & $(1.099)$ & EURATOM \\
\hline C- 186 & 1.009 & & \\
\hline C- 188 & 1.063 & & \\
\hline C-200 & 1.105 & & \\
\hline C-270 & 1.382 & & EURATOM \\
\hline C-271 & 1.169 & & EURATOM \\
\hline C -272 & 1.009 & & \\
\hline
\end{tabular}


TABLE XX (cont.)

\begin{tabular}{cccc} 
Source No. & $\begin{array}{c}\text { Yield Relative to } \\
\text { MRC-95 }\end{array}$ & IAEA & Location \\
\hline C-282 & 1.474 & & EURATOM \\
C-283 & 1.439 & EURATOM \\
C-297 & 1.102 & EURATOM \\
C-298 & 1.108 & EURATOM \\
C-299 & 1.138 & EURATOM \\
C-300 & 1.109 & \\
C-470 & 1.132 & \\
C-471 & 1.153 & \\
C-472 & 1.136 & \\
C-473 & 1.116 & \\
C-474 & 2.554 & \\
C-475 & 2.627 & \\
C-476 & 2.580 & \\
C-477 & 2.600 & \\
C-539 & 2.499 & \\
C-540 & 2.511 & IAEA \\
C-541 & 2.610 & \\
C-542 & 2.468 & \\
N-009 & 0.965 & IAEA \\
N-010 & 1.040 & \\
N-058 & 1.575 & \\
N-061 & 1.197 & \\
N-071 & 1.469 & \\
N-072 & 1.378 & \\
N-073 & 1.128 & \\
N-074 & 1.430 & \\
N-075 & 1.495 & \\
N-158 & 1.169 & \\
N-159 & 1.166 & \\
N-160 & 1.252 & \\
N-161 & 1.195 & \\
\hline MRC-95 has yield of $4.00 \times 10^{4} \mathrm{n} / \mathrm{s}$ on $85-06-01$. & \\
& & \\
\hline
\end{tabular}




\section{APPENDIX B \\ Updated version of Table $V$ from LA-11229-MS (Ref. 1)}

\begin{tabular}{|c|c|c|c|c|c|}
\hline Detector ID & $\begin{array}{c}\text { AmLi } \\
\text { Top/Bottom }\end{array}$ & $\begin{array}{c}\text { Net } T_{0}(\mathrm{AmLi}) \\
\left(\mathrm{s}^{-1}\right) \\
(\mathrm{yr}-\mathrm{mo}-\mathrm{d})\end{array}$ & $\begin{array}{l}\mathrm{Cf} \\
\mathrm{D}\end{array}$ & $\begin{array}{c}R_{0}(\mathrm{Cf}) \\
\left(\mathrm{s}^{-1}\right) \\
(\mathrm{yr}-\mathrm{mo}-\mathrm{d})\end{array}$ & $\frac{R_{N}(A W C C-r f f)}{R_{0}(A W C C-X X)}$ \\
\hline $\begin{array}{c}\text { AWCC (LANL/EUR) } \\
(\text { SN300) }\end{array}$ & MRC-116/115 & $\begin{array}{c}\sim 7110 \\
(84-09-05\end{array}$ & CR-5 & $\begin{array}{c}3058 \\
(87-06-03)\end{array}$ & $\sim 1.04$ \\
\hline $\begin{array}{c}\text { AWCC (IAEA-4699/1) } \\
\text { (AMPTEK) }\end{array}$ & MRC-114/113 & $\begin{array}{c}-6350 \\
(85-08-10)\end{array}$ & CR-5 & $\begin{array}{c}3012 \\
(87-06-01)\end{array}$ & 1.00 \\
\hline $\begin{array}{c}\text { AWCC (IAEA-4699/5) } \\
\text { (NNC-AMPTEK) }\end{array}$ & MRC-114/113 & - & CR-5 & $\begin{array}{c}2807 \\
(87-06-11)\end{array}$ & - \\
\hline $\begin{array}{l}\text { AWCC (EUR-2) } \\
\text { (main MTR) }\end{array}$ & C-180/176 & - & CR-5 & $\begin{array}{c}3160 \\
(87-06-10)\end{array}$ & - \\
\hline $\begin{array}{l}\text { AWCC (EUR-4) } \\
(8601801)\end{array}$ & C-298/297 & - & CR-5 & $\begin{array}{c}2953 \\
(87-06-02)\end{array}$ & - \\
\hline $\begin{array}{l}\text { AWCC (EUR-5) } \\
(8601802)\end{array}$ & C-300/299 & - & CR-5 & $\begin{array}{c}2934 \\
(87-06-3)\end{array}$ & - \\
\hline $\begin{array}{l}\text { AWCC (EUR-3) } \\
(\text { JCC51) }\end{array}$ & C-181/182 & $\begin{array}{c}7065 \\
(85-10-24)\end{array}$ & CR-5 & - & $\sim 0.913$ \\
\hline $\begin{array}{c}\text { AWCC (LANL-Black) } \\
\text { (AMPTEK) }\end{array}$ & MRC-100/99 & $\begin{array}{c}\sim 8880 \\
(87-05-05)\end{array}$ & CR-5 & $\begin{array}{c}2945 \\
(87-06-03)\end{array}$ & 0.840 \\
\hline $\begin{array}{l}\text { AWCC (LANL/AAEA) } \\
\text { (Canada unit) }\end{array}$ & MRC-81/82 & - & - & - & - \\
\hline $\begin{array}{c}\text { AWCC } \\
\text { (Aquila SN 1001) }\end{array}$ & N-073/061 & $\begin{array}{c}\sim 4667 \\
(95-8-23)\end{array}$ & CR-5 & $\begin{array}{c}3065 \\
(87-06-03)\end{array}$ & 1.12 \\
\hline $\begin{array}{l}\text { AWCC (Canberra } \\
\text { SN 04956568) }\end{array}$ & N-074/075 & $\begin{array}{c}\sim 6068 \\
(95-8-23)\end{array}$ & CR-5 & - & 0.864 \\
\hline
\end{tabular}



This report has been reproduced directly from the best available copy.

It is available to DOE and DOE contractors from the Office of Scientific and Technical Information,

P.O. Box 62,

Oak Ridge, TN 37831.

Prices are available from (615) 576-8401.

It is available to the public from the National Technical Information Service, US Department of Commerce, 5285 Port Royal Rd.

Springfield, VA 22161. 


\section{Los Alamos \\ NATIONAL LABORATORY \\ Los Alamos, New Mexico 87545}

